\title{
STRENGTHENING NATIONAL ECONOMIC GROWTH AND EQUITABLE INCOME THROUGH SHARIA DIGITAL ECONOMY IN INDONESIA
}

\author{
Amrin Barata \\ BPS Sulawesi Tenggara, Indonesia, baratalade@gmail.com or amrin.barata@bps.go.id
}

\begin{abstract}
The rapid progress of information and communication technology (ICT) creates a new look of the Indonesian economy, transforming from the conventional economy into a digital economy. The part of the digital economy currently developing worldwide, include in Indonesia is, Fintech (Financial Technology) and E-commerce. Additionally, Indonesia contributes to 4 percent of total e-commerce sales around the world. The development of Fintech in Indonesia is still at early stages, as many industries have not developed such a practice. Besides, there are many opportunities that have not been explored to its full potential. The research employs Input Output (I-O) analysis, using shock of IDR 3.90 trillion in investment of the sharia e-commerce subsector, we found through this study that the national economic growth grew by 0.048 percent or the economic output increased by IDR 5.08 trillion. As for the impact on gross value added (GVA) grew by 0.072 percent or increased by IDR 3.72 trillion. In addition, national labor income increased by IDR 795.36 billion with investment in sharia e-commerce subsectors. After an additional shock to the Fintech and the trade sector, economic growth increased by 0.052 percent or IDR 5.48 trillion. Sharia e-commerce and sharia Fintech should be able to have a big impact on the economic growth, increasing the amount of labor needed so that it can absorb more national labor. Thus, economic growth, increased income, and job creation will potentially reduce poverty and inequality in that the implications in the long term will further strengthen sustainable national economic growth.
\end{abstract}

Keywords: Economic Growth, I-O Analysis, Islamic Digial Economy. JEL Classification: C67; L81; O47.

\author{
Article history: \\ Received : October 31, 2018 \\ Revised : February 26, 2019 \\ Accepted : February 27, 2018 \\ Available online : March 15, 2019
}

https://doi.org/10.21098/jimf.v5i1.1053 


\section{INTRODUCTION}

The development and advancement of information and communication technology (ICT) lately have been enjoyed in various aspects of people's lives. The rapid technology also brings forward a new look for the Indonesian economy from the conventional economy into a digital economy (Kemkominfo, 2017).

High-speed connectivity is the basic building block of a digital economy. The digital economy leverages technology developments of the last 30 years to allow Indonesians to be part of the largest digital economy in Southeast Asia, access the government, e-commerce, education and information services, as well as communicates with fellow Indonesians or across the world. In a country of over 17,000 islands and more than 260 million people, availability of spectrum is critical to ensuring connectivity is available across the nation, providing all Indonesians with reliable and fast access (Robinson, 2018).

The manufacturing and retail sectors, characterized by low adoption of technology and high reliance on labor, stand to benefit the most. Online transactions account for a small percentage of total retail transactions. However, a Google study estimates that the total first-hand e-commerce market in South-East Asia is expected to reach around $\$ 88$ billion (IDR 1,277 trillion) by 2025, with Indonesia representing a significant proportion of the figure (Google and Temasek, 2018).

Under most definitions, the digital economy encompasses the ICT sector and e-commerce. However, the components of each differ by country (World Bank, 2018). The part of the digital economy that is currently developing including in Indonesia is Fintech and E-commerce. Head of BKPM, Thomas Trikasih said that Indonesia would be ready for a digital economy society, and it was projected by 2020, Indonesia could become the center of digital economy in ASEAN.

Figure 1 (appendix 1) shows that during Q-2014 to Q III-2018, the contribution of the Information and Communication sector and Other Financial Services to GDP was still very small. In Q III-2018, the contribution of other financial services sector, including conventional and sharia fintech services, was still below 1 percent (0.61 percent). Meanwhile, the information and communication sector, including e-commerce, was 3.75 percent. Even so, the contribution of the two sectors tends to increase from year to year. Even on average, the growth rate of the information and communication and financial services sector quarterly to the same quarter of the previous year was above the GDP growth rate, which grew about 8 - 9 percent, above 5 percent (Figure 2; see appendix 3 for original data). 
Figure 1. Distribution of the Information and Communication sector and Other

Financial Services to GDP Quarterly at Current Prices (Percent), 2014 - 2018

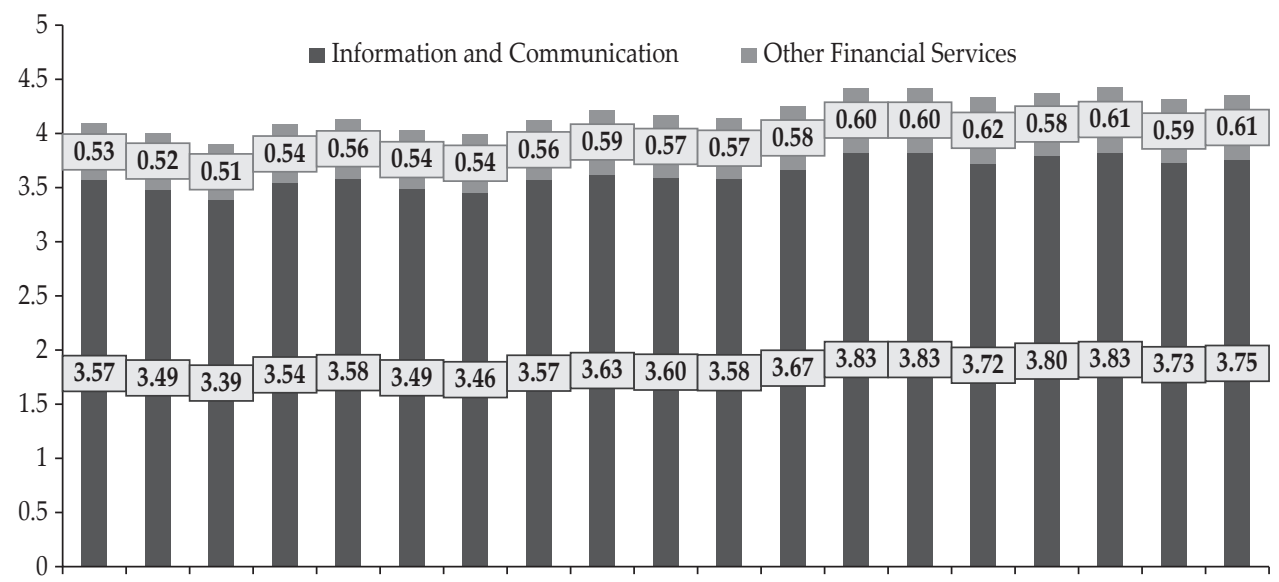

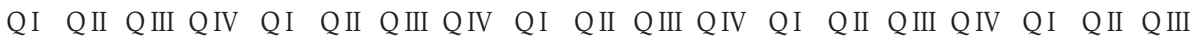
$\begin{array}{lllll}2014 & 2015 & 2016 & 2017 & 2018\end{array}$

Source : BPS (Data Processed)

Figure 2. Information and Communication Growth Rate, Other Financial Services, and GDP (percent) Quarterly to the Same Quarter of Previous Year (y-on-y), 2014-2018 (Constant Price 2010)

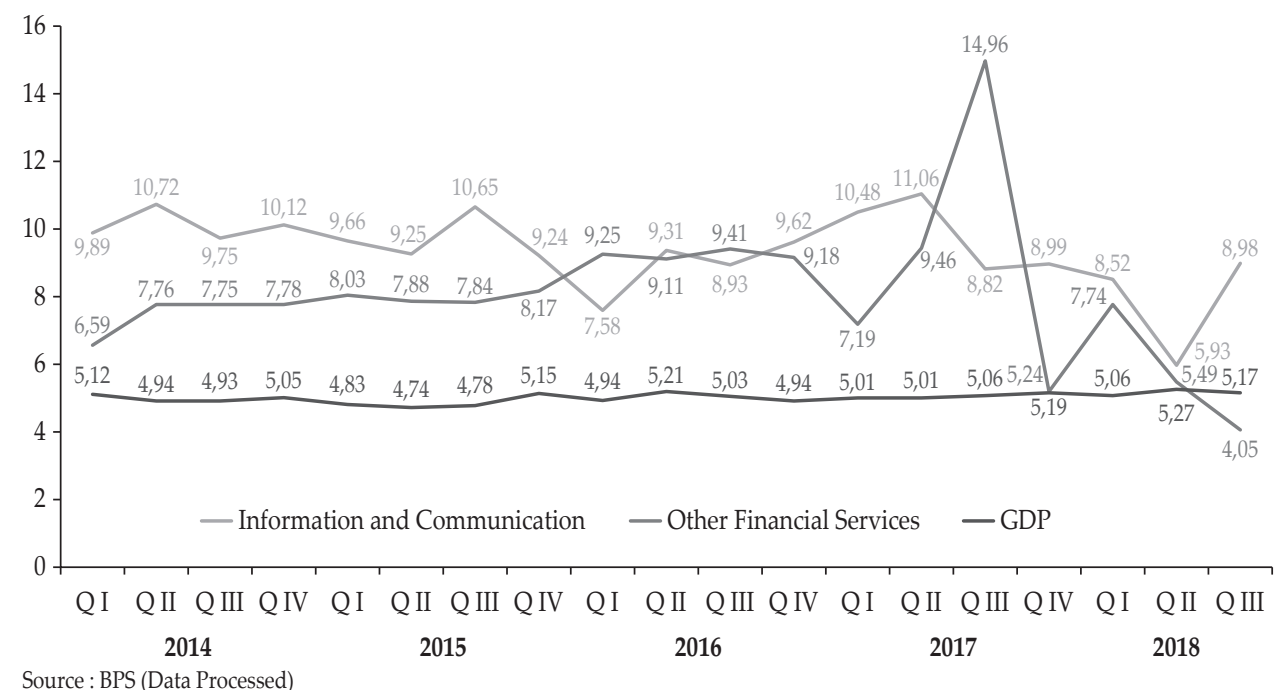

Source : BPS (Data Processed) 
Economic growth is generally defined as an increase in Gross Domestic Product (GDP), either in total GDP or in GDP per capita (Angelsen \& Wunder, 2006). Indonesia's economic growth averaged over 5 percent. It slowed down in 2015, but began to grow positively until 2017. Despite that, Indonesia's GDP per capita continued to increase from 2013 (IDR 32,781 thousand) to 2017 (IDR 37,851 thousand). However, how did it impact on poverty and inequality?

In this study we aim to calculate the potential impact of digital economy of Sharia E-commerce and Sharia Fintech in order to strengthen national economic growth and distribute income and wealth equitably. Because there is a large potential of Sharia E-commerce and Sharia Fintech in facilitating MSMEs in running their businesses, such a potential lends itself to job creation that will absorb more labor and increase income, in that it will reduce inequality and poverty. Further, it is expected that the economy will grow sustainably better with better distribution of income and wealth.

Some previous studies argue that the benefits of investment are included in the e-commerce and Fintech sector, but separately towards national and sectoral economic growth. However, there has not been a study on the impact of the sharia digital economy in both e-commerce and Fintech on economic growth. As such, sharia e-commerce and sharia Fintech have developed rapidly. The sharia digital economy is very important because sharia principles are very much needed by MSMEs and Muslim society. Unfortunately, previous studies have not combined Fintech and e-commerce sub-sectors towards national and sectoral economic growth. Therefore, this study focuses on answering such questions in this study.

A couple of other studies highlight several important points. One study shows an evidence of causality relationship between growth, poverty, and inequality. Another discusses poverty-reducing impact of economic growth, as economic growth remains the key vehicle for the reduction of income poverty in poor countries. However, it is crucial to find out not only the impact of sharia digital economy on economic growth in Indonesia, but also its potential for equitable income and wealth distribution for society.

\section{LITERATURE REVIEW}

\subsection{Fintech and E-commerce}

The digital economy is an economy-based computing and digital ICTs, which can be understood as consisting of three overlapping major components: the digital ICT infrastructure (hardware, software), the process of organizing through computermediated networks, and e-commerce (trading of goods or services online). Meanwhile, digital divides can be understood as the gap between individuals, households, businesses, and geographic areas at different socio-economic levels relevant to their opportunities to access information and communication technologies (ICTs), as well as their use of the internet (Azali, 2017).

Fintech is a software-based business and modern technology that provides financial services. Fintech companies in general are start-up companies that provide financial services and solutions to customers, by way of mobile payments, money transfers, loans, fundraising, and even asset management. Having said 
that, Sharia Fintech signifies financial services and solutions provided by Fintech technology/startup companies, based on Islamic/sharia laws (DDS Fintech, 2017).

The role of Fintech is to provide structural solutions for the growth of industries electronically (e-commerce) and encourage the growth of small and mediumsized (MSMEs) businesses and the birth of new entrepreneurs (Iman, 2016). The development of Fintech in Indonesia is still at early stages as many industries have not been fully integrated. However, many opportunities have not been explored to its full potential. Since Fintech is still developing at the early stages, it could be a good opportunity for Fintech sharia in Indonesia to take an important role.

Digitizing sharia economy can be expanded in various economic aspects, both in microeconomics and macroeconomics. At present, the role of digital economy is very unusual. Almost all economies use information and communication technologies or digitalization, both in product packaging products or marketing. Such a strategy makes the distribution of information easier and quicker and encourage economic growth more positively as there is no limit to the support digital technology and information technology (ICT) (Ansori, 2016).

The increasing number of internet development has led to various business lines, such as e-commerce, the proliferation of technology-based (startups), and digital financial services or financial technology (fintech). Fintech has advantages over traditional banks, in that it has the technology and innovation to reach customers who cannot access the traditional banking system. Fintech is also more efficient because it can reduce operating costs resulting in cheaper loan facilities. Sharia Fintech is feasible to take advantage of the great opportunity, especially with sharia principles that are expected to help Indonesian people who have MSME businesses. The digital era makes the opportunity for people to sell goods and services easier. Now, everyone can open a shop without having a physical store, and afford enough market through websites, e-commerce platforms, or social media.

Fintech sharia potentially opens greater opportunities for household consumers and the business community, including small and medium-sized businesses (MSMEs) to access financial services. In addition, Fintech Sharia offers convenience, speed of service, and lower costs, as well as convenience for consumers in enjoying financial services. The most important implications and dividends of the various benefits of Fintech Sharia are financial inclusion. This is further expected to drive sustainable national economic growth and enable diversification of exposure to investment risks as a whole (Nizar, 2018).

The use of information technology in running a trading business or often known as e-commerce for small companies provides flexibility in production, enables faster delivery to customers for software products, sends and receives offers quickly and economically, and supports fast transactions without paper (Widgeon, 2016). The development of information technology, especially using the Internet, creates a virtual space and replaces the physical space on the earth. E-commerce activities occur through the virtual space, although in some parts of the system it still uses physical space. Smartphone penetration, already enhanced with Internet access to diverse user communities, makes e-commerce develop even more rapidly (Widagdo, 2016). 
According to Triton (in Nizar, 2018), e-commerce is a process of buying and selling products electronically by consumers or from companies to companies that use computer media as an intermediary for business transactions. Hidayat (in Nizar, 2018) argues that e-commerce has several advantages, including many types of products that can be marketed and sold through the internet, such as cars, clothes, TV, to name a few. Marketplace products using the Internet must have a domain and hosting and a place to receive orders by emails, telephones, texts, and others. Payment method is normally credit card, PayPal, or cash. The shipping method utilizes courier services, and customer service draws on emails, $\mathrm{CP}$, chats, many others. However, although such a concept of e-commerce is widely accepted, sharia e-commerce may be implemented differently due to certain restrictions by the sharia rules, especially in payment methods.

\subsection{Economic Growth and Inequality}

Economic growth is the process of continually changing a country's economic condition toward a better condition in a certain period. Economic growth can also be interpreted as a process of increasing production capacity of an economy that is realized in the form of an increase in national income. Economic growth is an indication of the success of economic development in people's lives. Economic growth of a country can be measured by comparing, for example, to the national size, Gross Domestic Product (GDP), and the current year with the previous year.

The World Bank breaks the population up into three groups according to the income size: $40 \%$ of the population with low income, $40 \%$ of the population with middle income, and $20 \%$ of the population with high income. In Indonesia, income inequality is measured by the percentage of income from the lowest income group of $40 \%$ compared to the total income of the entire population (BPS, 2018). Central Bureau Statistics of Indonesia (BPS) creates an indicator called Gini Ratio to see income/expenditure inequality in a region. Gini Ratio is ax measure of inequality whose value ranges from $0-1$.

\subsection{Previous Studies}

The INDEF study (2017) is entitled "The Impact of Financial Technology Funding on the Indonesian Economy" with a focus on its impact on economic growth, sectoral output, and job creation. The analysis in this study uses Input-Output to find out how much the benefits of investment are included in the field of Fintech both on national and sectoral economic growth. The I-O data used were the I-O data in 2010. The results of statistical tests indicate that Fintech increased GDP by IDR 25.97 trillion in less than two years. At the same time, Fintech is able to stimulate growth sectorally, including the financial services, insurance, business services, pension funds, and information system. Additionally, Fintech absorbed a workforce of 215,433 people and added labor income in the form of wages and salaries amounting to IDR 4.56 trillion. Fintech lending was also proven to increase the economy through lending, especially to the MSMEs sector (Abdullah, 2018).

INDEF's research entitled "The Influence of the E-Commerce Sector on Economic Growth" uses the Input-Output analysis to find out how much the 
benefits of investment are included in the e-commerce sector towards national and sectoral economic growth. The I-O data used were I-O data in 2010 because there was no change in the structure of the economy in 2010 to 2017. This study investigated 17 economic sectors to see which economic sectors had a significant impact on e-commerce investments. The conclusion of this study is that e-commerce sales in Indonesia were still likely to grow up to 300 percent by 2021. Investment in the e-commerce sector was USD 4.8 billion in 2017, providing an output growth benefit of 0.712 percent (Adhinegara, 2018).

The most common measure of income inequality is the Gini coefficient or index (G). The Gini coefficient has a value between 0 and 1, with 0 being perfect equality (all have the same income) and 1 being perfect inequality (all income earned by one person). In most countries, it ranges between 0.3 and 0.7. The Gini coefficient can thus be intuitively interpreted as the share of the total income (GDP) that has to be redistributed to hypothetically obtain perfect income equality. Experiences in East and Southeast Asia (Taiwan, South Korea, Thailand, Hong Kong, Singapore, Malaysia, Indonesia) provide ample evidence of the poverty reducing impact of economic growth. Economic growth remains the key vehicle for the reduction of income poverty in poor countries ((Angelsen \& Wunder, 2006).

Some previous studies have focused on cross-country regressions of GDP growth on income inequality. They unanimously reveal a negative correlation between the average rate of growth and a number of measures of inequality. To illustrate, Benabou (1996) provides a review of recent empirical literature that challenged the pro-growth effect of rising inequality of income. Similarly, Aghion et al. (1999) list three reasons why inequality may have a direct negative effect on growth. First, inequality reduces investment opportunities. Second, inequality worsens borrowers' incentives. Third, inequality generates macro-economic volatility. They also suggest that redistribution to the less endowed, by reducing inequality, could therefore be growth enhancing in such an economic environment. Moreover, Persson \& Tabellini (1991) contends that inequality is harmful for growth. They argue that a society where distributional conflict is more important, political decisions are more likely to produce economic policies that allow private individuals to seek rents (Shaikh, 2016).

INDEF research entitled "Growth, Poverty and Inequality Trianglein Indonesia" investigated the causality relationship between growth, poverty, and inequality carried out by Panel Granger Causality method. The data were the percentage of the province's poor population, the data of economic growth per province, and the Gini index each province since 2007-2016. The conclusion obtained from the analysis of the relationship between economic growth, inequality, and poverty through the Granger Causality approach is that inequality in Indonesia has a twoway causality with poverty and poverty has two-way causality with economic growth (Abdullah, 2018).

\section{METHODOLOGY}

\subsection{Data}

The data used in this study were secondary data derived from the Indonesian Input-Output (I-O) Table in 2008 with a classification of $66 \times 66$ in the production 
sector, published by the Central Bureau Statistics of Indonesia (BPS). This was due to the structure of the Indonesian economy that did not change too much until 2017-2018, dominated by the agricultural sector even though the trend tended to decline. The shock incorporated the 2017-2018 data from various economic, financial, investment research institutions (INDEF, BPS, OJK, BKPM, and others).

\subsection{Estimation Technique}

The analytical tool used is impact analysis using the inverse matrix (multiplier matrix) obtained or derived from the basic tables. Impact analysis includes the impact on output, the impact on wages and salaries, the impact of household consumption, and others.

Analysis with the I-O model was based on a table of a matrix that presents information about transactions of goods and services in the size of the monetary unit, for example the rupiah, and the interrelationships between units of economic activity (sectors) in an area for a certain period called I-O Tables. Such an analysis is suitable for the field of planning economics due to its ability to perceive sector by sector in the economy on a comprehensive level (Firmansyah, 2006). Technological changes and relative prices can be integrated into the model through changes in the technical coefficients. The Input-Output matrix is as follows:

Table 1.

Input-Output Matrix Table for Economic Systems by Three Production Sectors

\begin{tabular}{lcccccc}
\hline $\begin{array}{l}\text { Output Allocation } \\
\text { Input Structure }\end{array}$ & \multirow{2}{*}{$\begin{array}{c}\text { Intermediate Demand } \\
\text { Production Sector }\end{array}$} & \multirow{2}{*}{$\begin{array}{c}\text { Final } \\
\text { Demand }\end{array}$} & & Import & $\begin{array}{c}\text { Total } \\
\text { Output }\end{array}$ \\
\hline Intermediate Input & \multicolumn{2}{c}{ Quadrant I } & & Quadrant II & \\
\hline Sector 1 & $\mathrm{X}_{11}$ & $\mathrm{X}_{12}$ & $\mathrm{X}_{13}$ & $\mathrm{~F}_{1}$ & $\mathrm{M}_{1}$ & $\mathrm{X}_{1}$ \\
Sector 2 & $\mathrm{X}_{21}$ & $\mathrm{X}_{22}$ & $\mathrm{X}_{23}$ & $\mathrm{~F}_{2}$ & $\mathrm{M}_{2}$ & $\mathrm{X}_{2}$ \\
Sector 3 & $\mathrm{X}_{31}$ & $\mathrm{X}_{32}$ & $\mathrm{X}_{33}$ & $\mathrm{~F}_{3}$ & $\mathrm{M}_{3}$ & $\mathrm{X}_{3}$ \\
\hline & \multicolumn{7}{c}{ Quadrant III } & & & \\
\hline Primary Input & $\mathrm{V}_{1}$ & $\mathrm{~V}_{2}$ & $\mathrm{~V}_{3}$ & & & \\
Total Input & $\mathrm{X}_{1}$ & $\mathrm{X}_{2}$ & $\mathrm{X}_{3}$ & & & \\
\hline Source: BPS & & & & &
\end{tabular}

\subsection{Empirical Model}

The input and output data presented in the Input-Output table illustrate the intersectoral linkages in the economy. Analysis using table I-O is an economic analysis that is bound by the basic assumptions that underlie its compilation, like the assumptions of homogeneity, proportionality, and additivity.

The input-output table is a system of presenting statistical data on transactions of goods and services between economic sectors that occur in an area presented in the matrix form. Output distribution from sector $(i)$ is described in mathematical equations as follows, 


$$
X_{i}=z_{i 1}+z_{i 2}+\ldots+z_{i n}+Y_{i}
$$

Where : $X_{i}=$ total output sector $i$;

$Y_{i}=$ total final demand sector $i$;

$\mathrm{z}_{\mathrm{ij}}=$ flow of goods value from sector $i$ to sector $j$

The relationship between the output of sector $j$ and the input coming from sector $i$ is reflected in the coefficient of input-output $\left(a_{i j}\right)$ or commonly called the technical coefficient and can be expressed as:

$$
a_{i j}=\frac{z_{i j}}{X_{j}}
$$

\subsubsection{Leontief inverse matrix}

The inverse matrix of Table I-O is the basic framework for various economic analyzes. In principle, the matrix is a function that connects the final demand to the production level. Therefore, the inverse matrix can be used to calculate the effect of the final demand changes on various sectors in the economy (BPS, 2008).

$$
\mathrm{X}=(\mathrm{I}-\mathrm{A})-1 \mathrm{Y}
$$

Alternatively, what is known as a general form of open input-output models analysis.

\subsubsection{Impact analysis}

1. Impact of final demand to output

The impact of the final demand on an output can be calculated by the formula:

$$
\begin{aligned}
& X F T=(I-A)-1(F-M), \text { or } \\
& X F D=(I-A d)-1 F d
\end{aligned}
$$

where, $X_{F T} \quad$ : the output formed due to the impact of all final demands

$X_{F D} \quad$ : the output formed due to the domestic final demand impact $\left(X_{\mathrm{FT}}=\mathrm{X}_{\mathrm{FD}}\right)$

$\left(I-A^{d}\right)^{-1}$ : Leontief inverse matrix with domestic input

$F-M$ : components of final demand or domestic final demand components $\left(\mathrm{F}^{\mathrm{d}}\right)$

2. Income impact analysis

The relationship between income and output is linear, so it can be written:

$$
\mathrm{W}=\widehat{w} X
$$

where: $\mathrm{W}=$ Income matrix;

$\widehat{W}=$ Diagonal matrix of income coefficient;

$\mathrm{X}=\left(I-A^{d}\right)^{-1} F^{d}$ 


\section{RESULTS AND DISCUSSION}

Throughout 2017-2020, it was predicted that there would be 32.3 million new Internet users in Indonesia, making it the third largest social media users growth throughout the period. Indonesia also contributed around 4 percent of total e-commerce sales around the world. Throughout 2017 Indonesian start-up companies received an investment of USD 4.93 billion (BKPM, 2018).

Economic census 2016 data released by Central Bureau Statistics of Indonesia (BPS) informed that the e-commerce industry in Indonesia grew about 17 percent with a total about 26.2 million enterprises. E-commerce provides benefit for the Indonesian society, especially Muslims. Because the platform generally does not use a credit card payment system, the transaction is also expected to be free from usury (riba). This is a big economic potential due to the large Muslim population in Indonesia (about 200 million/80 percent).

In 2016, Indonesia was recorded as the country with the highest number of startups in Southeast Asia, totaling up to 2,000 or more. The number of technology-based startups in Indonesia is projected by the CHGR (Centre for Human Genetic Research) research institute to grow by 6.5 times to 13,000 by 2020, encapsulating many aspects of businesses to drive the growth from public digital transformation, investment flows, to government support. The increasing digital economy potentials could be utilized by Indonesian society wishing to improve their businesses in the modern era, especially with sharia principles. Let us find out how great of an impact of Islamic digital economy is in the field of e-commerce and Fintech on national economic growth.

Indonesia's digital economy is for now still in its infancy, though one estimate of the potential impact of digital technologies in the country suggests an increase in GDP of $\$ 150$ billion (IDR 2,160 trillion, which translates to 16 percent growth on current GDP) by 2025 and 3.7 million additional jobs (McKinsey \& Company, 2016).

\subsection{Impact of investment in Sharia E-commerce on Economic Growth and Gross Value Added}

Analysis of I-O in this study uses a shock of 6 percent from USD 4.8 billion in 2017, which was the total investment obtained by e-commerce companies. Multiplied by the average rupiah exchange rate in 2017 of IDR 13,555, the total investment obtained was IDR 65.06 trillion. The sum was utilized only 6 percent as a proxy of sharia investment for e-commerce companies, amounting to IDR 3.90 trillion. The number is shocked to information and communication (ICT) sector investment (PMTB).

The results obtained were the national economic growth grew by 0.048 percent with the addition of sharia investment in the e-commerce sector or the economic output that increased by IDR 5.08 trillion. By sectors, additional sharia investment in the e-commerce subsector had the most impact on the economic growth are the ICT sector itself (2.2 percent or IDR 4.19 trillion), financial institutions (0.052 percent), electricity, gas and clean water (0.048 percent), real estate and corporate services ( 0.031 percent), as well as the paper industry, goods of paper and cardboard (0.03 percent). All sectors were closely related to internet-based technology. As for 
the impact on gross value added (GVA), it grew by 0.072 percent or increased by IDR 3.72 trillion.

The impact on the trade sector was not too large, only by 0.005 percent. This could be due to the small portion of sharia investment in the e-commerce subsector to total trade. Data compiled from statista.com, Indonesia's e-commerce total revenue up to September 2018 (mostly conventional e-commerce) was USD 9.53 billion or IDR 133.5 trillion, including fashion (IDR 32.3 trillion); electronics and media (IDR 37 trillion); food and personal care (IDR 20.3 trillion); furniture and appliance (IDR 23.4 trillion); and toys, hobbies \& DIY or "Do It Yourself" (IDR 20.4 trillion). The revenue growth increased by 23.3 percent compared to 2017. The penetration of e-commerce users is as much as 107 million people $(40 \%$ Indonesian population) which is up 5.9 percent from the users in 2017, as many as 83 million Indonesians (31 percent) who bought something online via a phone in the past month (m-commerce penetration) (Kemp, 2018). In 2016, the portion of online trading accounted for was no more than 1 percent of total retail (AC Nielsen survey in INDEF Monthly Policy Brief, 2017). However, both in terms of user and revenue, the growth of e-commerce was significant. IPrice's State of e-commerce reported at the end of 2017 stated that Indonesia was the highest share of mobile traffic country in Southeast Asia, which is 87 percent of total traffic. Accordingly, it is certainly a great opportunity for sharia investment in the e-commerce sector (ICT) to take the important role because Indonesia obviously has a large market potential for this sector with high Muslim population and Internet users.

\subsection{Impact of Sharia E-commerce on Labor Compensation}

The results indicate that national labor income increased by IDR 795.36 billion with investment in e-commerce sharia subsectors. Communities relevant to the sector received an increase in income or wages due to the development of investment in the e-commerce sharia. The increase in capital obtained from E-commerce sharia investment made people's income increase. The additional income was indeed small because investment in sharia e-commerce was still relatively small. However, the value would continue to grow along with the growth of investment in the sector, which means that this sector is still very possible to continue grow in strengthening the general national economy.

\subsection{Impact of Investment in Sharia E-commerce, input in Sharia Fintech Financing and Trade Sector, given Loans by Fintech, on Economic Growth and Sectoral Output}

After using sharia investment shock of IDR 3.90 trillion in the e-commerce sector, the next scenario used in this study is:

1. Adding input to the financial institution sector where Fintech enters it. The additional input is amount of IDR 5.69 trillion obtained from the portion of Indonesia's GDP multiplied by amount of Fintech investment in the world which reaches USD 27.4 billion (INDEF, 2018). Since the Islamic finance inclusion in Indonesia is around 6 percent, it is estimated that additional input for Fintech sharia will be IDR 341.4 billion. 
2. Adding input to the trade sector, currently a sector given loans by Fintech. In general, the amount reached IDR 7 trillion until mid-2017. However, Indonesian Financial Services Authority (OJK) estimated that Fintech Sharia channeled financing of IDR 60 billion.

After an additional shock to Fintech subsector and trade sector that has been given loans by Fintech, economic growth increased by 0.052 percent, which amounted to IDR 5.48 trillion. The impact could still change as Fintech develops in the next few years.

As far as sectors are concerned, the sector with a significant impact of Investment in E-commerce sharia, input in Sharia Fintech financing, and trade sector given loans by Fintech were financial institutions, the information and communication sector (ICT), and electricity. Financial institutions experienced growth because Fintech sharia was closely related to Islamic financial institutions. The development of Fintech sharia also enhanced the information and communication sector (ICT), as the basis of Fintech management. Likewise, the electricity sector enjoyed some growth, as Fintech runs using electricity.

Expansion of access and utilization of digital applications is believed to make a more real contribution for the development of Indonesia's economy in the form of the growth in digital economy companies. The potential of MSMEs or start-ups in Indonesia is actually large, but the businesses need to be encouraged to partner with large-scale investors so that it can increase the business economic scale. This is what BKPM attempted to do with various parties involved to jointly commit to encourage Indonesian start-up partnerships with global business networks. Startups or MSMEs involved include the Industrial sector, food, beverage and business sectors, herbs and aromatherapy, jewelry, craft and accessories, fashion, bags and leather jackets (BKPM, 2018). Such good opportunities should be utilized by Islamic financial institutions, especially Islamic Fintech to take an important role.

\subsection{Impact of Input in Sharia Fintech Financing and Trade Sector (That Has Been Given Loans by Fintech) on Household Consumption}

After the additional shock by input to the Fintech subsector and trade sector that has been given loans by Fintech, household consumption increased by IDR 240.40 billion. Such an increase in household consumption had an impact on general economic growth. As far as sectors are concerned, the most consumption increase occurred in sectors directly related to Fintech sharia, such as electricity use. This is because the use of technology-based devices cannot be separated from electricity consumption.

Although the impact on household consumption was still relatively small, the number was still potential to continue grow along with the increase of investment in the Fintech sharia sector.

Sharia Fintech market in Indonesia, especially payment and Islamic lending, is a great potential considering the majority of Indonesia's Muslim (88.8\%), with as many as 64 percent still unbanked. The market potential of Islamic banking loan services was IDR 57 - 82 trillion in 2016, while the loan potential of the unbanked population was IDR 101.3 - 145.7 trillion. 


\subsection{What is the Standpoint of All Impact by General (Conventional and Sharia) Investment in E-commerce, and Input in Sharia Fintech Financing and Trade Sector (That Has Been Given Loans by Fintech)?}

If we want to see great opportunities that can be done by the public or investors in the e-commerce sector and Fintech financing to national economic growth, then we could see the impact in general with the combination of conventional and sharia. It is intended that with Islamic financial institutions, potential investors to invest in sharia can see great opportunities in the e-commerce and Fintech sectors.

With a shock of IDR 66.06 trillion for investment in e-commerce (ICT), additional input into the financial institution sector where Fintech was included was IDR 5.69 trillion, and additional input to the trade sector given loans by Fintech was IDR 7 trillion. Then the following results are obtained:

1. Economic growth increased by 0.925 percent, which amounted to IDR 97.44 trillion. The impact can still change as Fintech develops in the next few years.

2. The impact on gross value added (GVA) grew by 1.19 percent or increased by IDR 62.02 trillion.

3. Increased household consumption by IDR 7.46 trillion. The increase in household consumption will have an impact on general economic growth.

4. National labor income increased by IDR 13.26 trillion, which means that labor also increased to meet with national labor demand.

Such a significant impact has the potential to be explored by financial institutions to channel their financing in sharia. This is because up to February 2018, Indonesia's Islamic financial assets peaked at IDR 1,117.88 trillion (excluding Islamic stocks), consisting of IDR 542 trillion of state sukuk; IDR 429.36 trillion in Islamic banks; and IDR 99.31 trillion in Sharia IKNB. In 2016 alone, the potential market for banking loan services amounted to IDR 57 - 82 trillion, while the loan potential of the unbanked population is IDR 101.3 - 145.7 trillion (Business Review of Fintech Syariah, 2016). Not only in the e-commerce sector (ICT) and Fintech/financial institutions, but will also affect other sectors such as electricity procurement, real estate and corporate services, manufacturing, trade, and other sectors. What's more in this modern era, many sectors and businesses/agencies are utilizing ICT applications such as web and android-based applications. This will obviously encourage economic growth.

According to Ashari (2011), the ICT sector could penetrate a wide range of market segments, including:

1. The Health Industry, requiring applications such as Electronic Medical Records, Tele Medicine, Hospital Information System, Emergency Support System, Patient Identification Smartcard, Billing Management System, Integrated Insurance Management System, and others;

2. The Transportation Industry, potential for various systems related to Intelligent Traffic Control, Ticketing Management, Reservation Module, Cargo Management, and others;

3. The Retail and Distribution Industry, in need of assistance by a system such as Inventory Management, Geographical Information System, Retail Management, Network Optimization Module, and so on;

4. The Education Industry, to help increase its competitiveness through the implementation of E-Learning, Computer Based Training Module, Integrated 
Academic Information System, Mobile Learning, Library Management System, Virtual Campus, and others.

5. Other generic needs that are also needed by each industry in its efforts to increase competitiveness, such as: Accounting Management System, VoIP-Based Communication Model, e-Procurement, Intranet and Extranet, Decision Support System, Management Information System, Centralized Data warehouse, and so on.

With the opening of markets and increasing awareness of competitiveness, undoubtedly the ICT industry in Indonesia will develop rapidly. All of these market opportunities are wide open for use by sharia Fintech and sharia e-commerce. Besides making it easier for the community or society, all of that will also increasingly require a reliable workforce in that it will further open up employment opportunities for the Indonesian people. This certainly will further strengthen national economic growth.

\subsection{Impact of Sharia E-commerce and Sharia Fintech Financing on Equitable Income and Wealth Distribution}

Indonesia's economic growth averaged over 5 percent. It had slowed in 2015 (Figure 3 ), and then began to grow positively until 2017. In spite of that, Indonesia's GDP per capita continued to increase from 2013 (IDR 32,781 thousand) to 2017 (IDR 37,851 thousand).

Figure 3. GDP Per Capita and Economic Growth of Indonesia (2010=100), 2013-2017

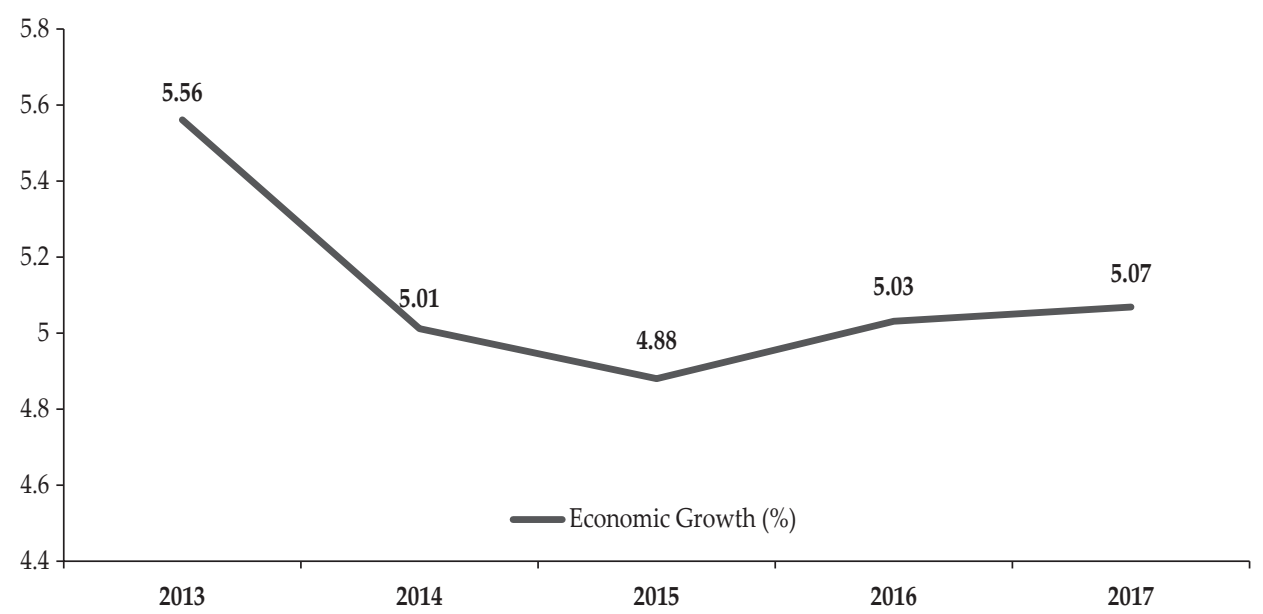


Figure 3. GDP Per Capita and Economic Growth of Indonesia (2010=100), 2013-2017 (Continued)

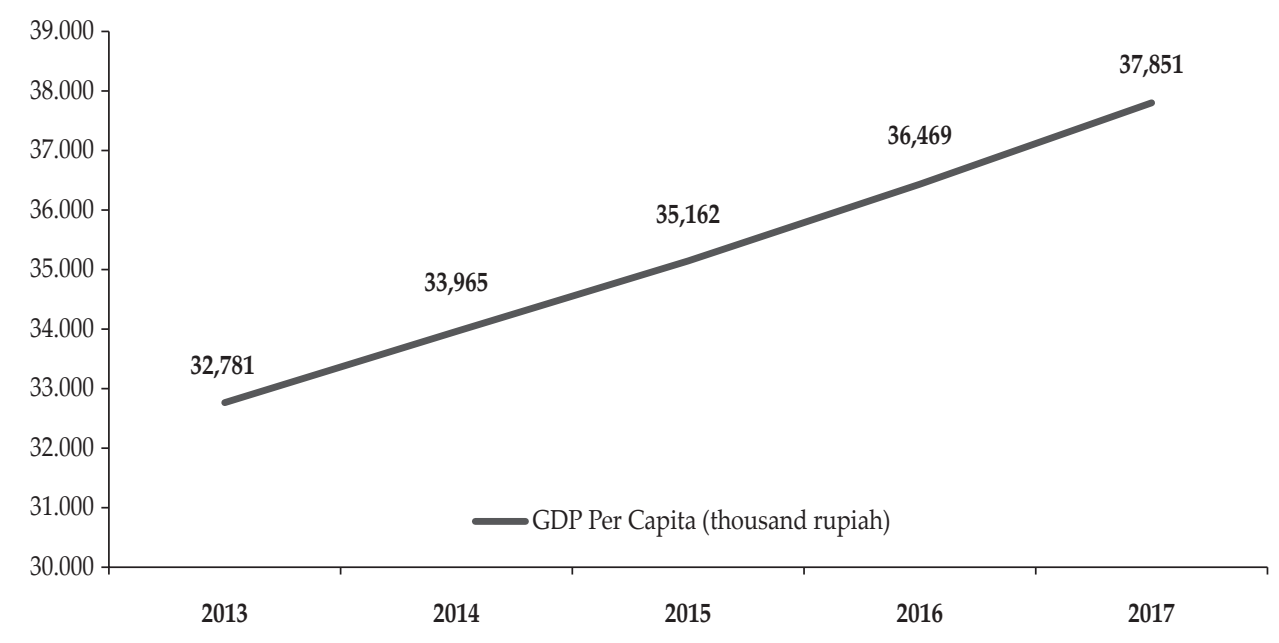

Source : BPS (Data Processed)

Theoretically, economic growth has a negative effect on poverty. It means that the higher the economic growth in a country, the lower the poverty level. Based on Figure 4 below, gini ratio (inequality) and percentage of unbanked Indonesian population (poverty) shows a downward trend from March 2013 to March 2018. This is an early indication that increasing national economic growth along with the decline in inequality and poverty, in order that distributing income and wealth can be better (appendix 2 and 4).

Figure 4. Gini Ratio and Poor Indonesian People (\%), 2013 (March) - 2018 (March)

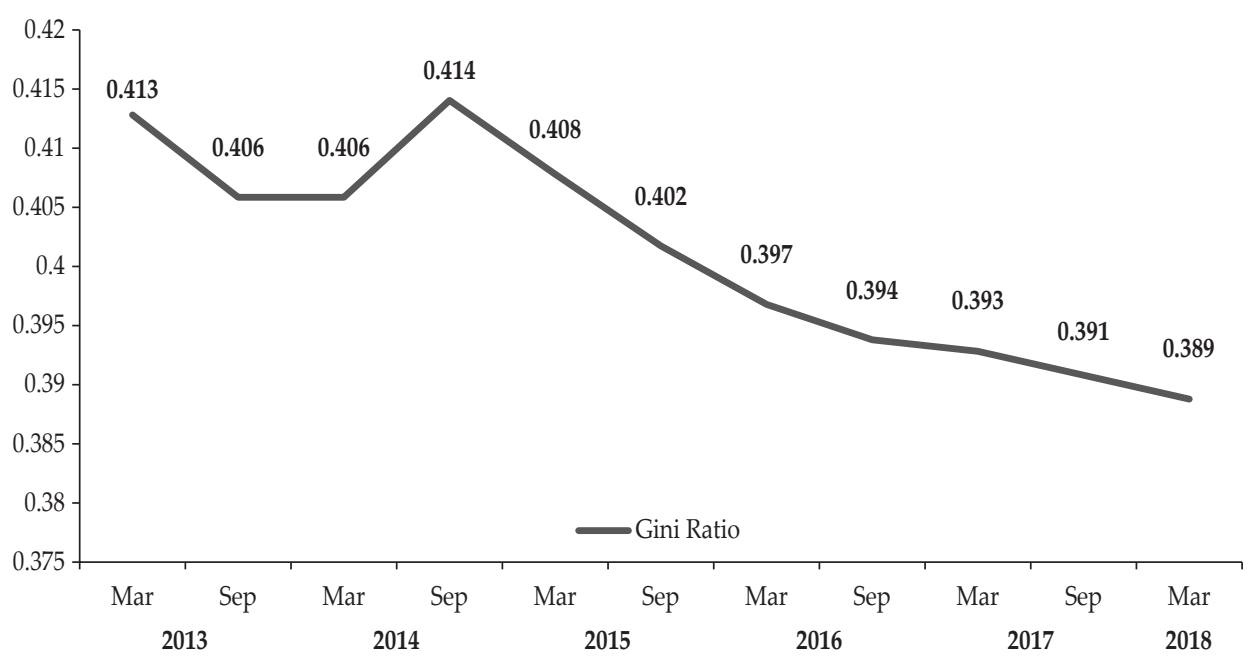


Figure 4. Gini Ratio and Poor Indonesian People (\%), 2013 (March) - 2018 (March) (Continued)

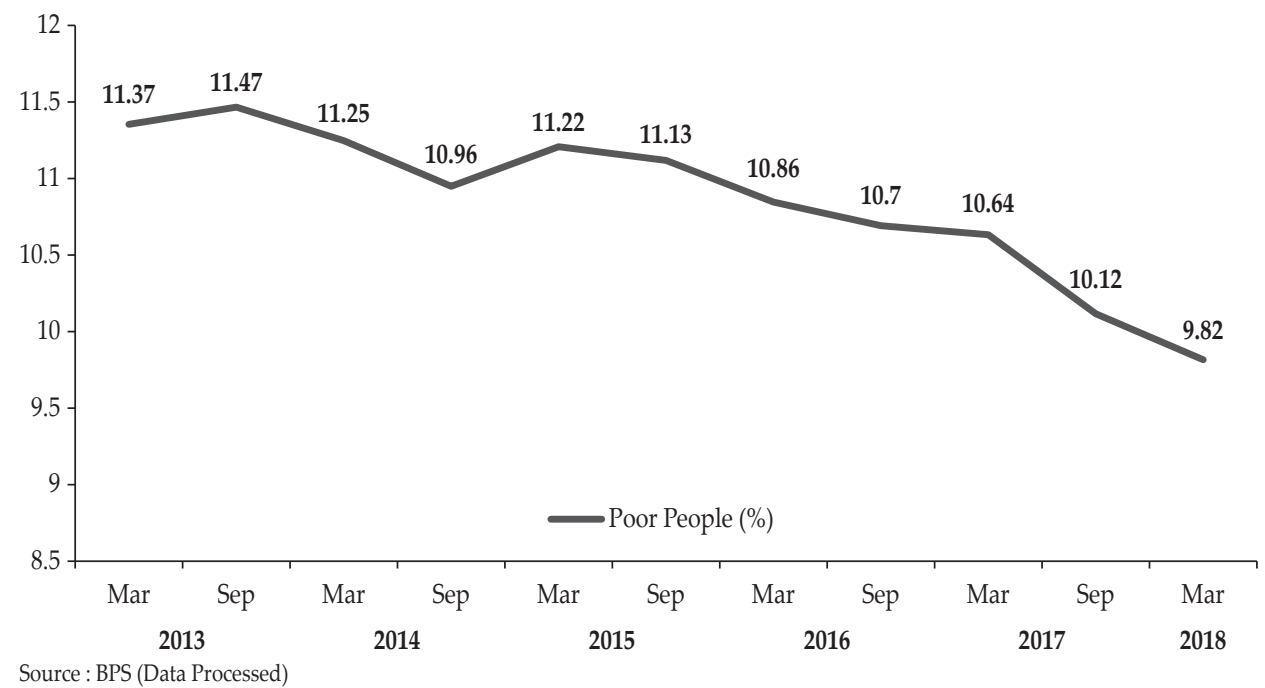

Equally important, Sharia e-commerce and Sharia Fintech have a significant impact to strengthen national economic growth. Equitable distribution of income and wealth can be overcome by solving the problem of poverty and inequality. In this case, we link this research with the results of research conducted by INDEF (2018) on the "Growth, Poverty and Inequality Triangle in Indonesia". Causality relationship between growth, poverty and inequality is done by the Granger Causality panel method, using data from 33 provinces in Indonesia and 10 years observation from 2007-2016. The results show that there is a 2-way causality between poverty and inequality and between economic growth and poverty. There is no direct causality between economic growth and inequality. This means that economic growth can reduce poverty, and a decrease in poverty can reduce inequality. Especially for ICT (include sharia e-commerce) and other financial services (including Islam Fintech) that continue to growth, consistent with the reduction in poverty and inequality in Indonesia. Moreover, sharia principles actually really help the economy of the Indonesian people, especially MSMEs business scale, as they indisputably need that.

Such a notion is related to the previous I-O analysis. Investment in the sharia e-commerce and sharia Fintech sectors will increase national economic growth and increase income significantly, which in return will create jobs in the e-commerce and Fintech sectors and other sectors that have links with the sector, especially providing large benefits to the community associated with MSMEs. Sharia Fintech and Sharia E-commerce are a great potential in facilitating the community, especially the community with SMEs to develop their business. From the results of the previous I-O analysis, the Islamic digital economy has a large impact in increasing income and absorbing labor, if investment management can be managed properly. Thus, the economic growth, an increased people's income, 
and job availability will reduce poverty and inequality. If poverty and inequality decreases, then equitable distribution of income and wealth will be better in Indonesia. In this case, the implications in the medium term will further strengthen national economic growth.

\section{CONCLUSION AND RECOMMENDATION}

\subsection{Conclusion}

Based on the analysis that has been carried out, the following important points can be concluded:

1. By using shock of IDR 3.90 trillion in investment of the e-commerce sharia subsector, the national economic growth grew by 0.048 percent or the economic output increased by IDR 5,08 trillion. As for the impact on gross value added (GVA), it grew by 0.072 percent or increased by IDR 3.72 trillion. In addition, also national labor income increased by IDR 795.36 billion with investment in e-commerce sharia subsectors.

2. The next scenario used in this study is adding input to the financial institution sector where Fintech enters it. The additional input was IDR 341.4 billion. In addition, the trade sector that is currently a sector that has been given loans by Fintech was added input of IDR 60 billion. After the additional shock, economic growth increased by 0.052 percent, which amounted to IDR 5.48 trillion.

3. Input addition to the Fintech subsector and trade sector (that has been given loans by Fintech) also increased household consumption by IDR 240.40 billion. Such an increase in household consumption will have an impact on general economic growth. Although the impact on household consumption is still relatively small, the number is still potential to continue grow along with the increase of investment in the Fintech sharia sector.

4. By looking at Islamic financial assets in Indonesia, E-commerce sharia and Fintech Sharia should be able to have the big impact on the economic growth. By the shock of IDR 66.06 trillion for investment in e-commerce (ICT) sector, additional input into the financial institution sector where Fintech was included was IDR 5.69 trillion. An additional input to the trade sector where currently many were given loans by Fintech was to IDR 7 trillion. Impact of the economic growth increased by 0.925 percent or IDR 97.44 trillion. In addition, it could increase household consumption by IDR 7.46 trillion, which would impact on gross value added (GVA) up to 1.19 percent or IDR 62.02 trillion. National labor income increased by IDR 13.26 trillion. As such, the amount of labor needed will also increase to absorb more national labor.

5. Especially for ICT (including Sharia e-commerce) and other financial services (including Islam Fintech) that continue to grow, they should be consistent with the reduction in poverty and inequality in Indonesia. Moreover, sharia principles actually really help the economy of the Indonesian people, especially MSMEs business scale. Investment in the sharia e-commerce and sharia Fintech sector will strengthen national economic growth and increase income. This will create jobs in the e-commerce and Fintech sectors and other sectors that have links with the sector, especially providing large benefits to the community associated with MSMEs. Sharia Fintech and Sharia E-commerce 
are a great potential in facilitating the community, especially the community with MSMEs to develop their business. From the results of the previous I-O analysis, the Islamic digital economy has a large impact in increasing income and absorbing labor, if investment management can be managed properly. As a result, economic growth, an increase in people's income, and job availability will reduce poverty and inequality. If poverty and inequality decrease, then equitable distribution of income and wealth will be better in Indonesia. The implications in the medium term will further strengthen sustainable national economic growth.

\subsection{Recommendation}

The recommendations for various stakeholders that help for improvement are as follows:

1. The development of Fintech in Indonesia is still at its early stages, as many industries have not developed the practice. On the other hand, many opportunities have not been fully explored. This should be used by sharia Fintech so that they can take a large part. This paper presents the relationship between investment funds and the impact on economic growth, through sharia digital economy with the hope that stakeholders can review policies relevant to fintech development.

2. As for the government, increased Internet connectivity and mobile devices are required throughout infrastructure development in Indonesia so that Sharia Fintech and Sharia E-commerce can be accessed and utilized by all groups, especially in the MSMEs business scale. However, the easy facilities in the digital economy are usually used by people who are not responsible for making large profits by utilizing the lack of knowledge of the society. Therefore, it needs some determination and supervision from stakeholders and the government.

3. As far as practitioners are concerned, the need for collaboration to jointly develop Sharia Fintech and Sharia E-commerce in Indonesia for mutual benefit.

4. In terms of academics, subsequent research should be conducted toward a more comprehensive analysis of input-output tables with wider inputs linked sectors besides e-commerce, Fintech, and trade, including manufacturing, electricity supply, and others.

5. For regulators, strengthening sharia principles in the development of Islamic digital economy, especially in the e-commerce and Fintech sectors will become the next objective.. As such, it is important not only in increasing and strengthening economic growth, but also in reducing poverty and inequality in Indonesia toward equitable distribution of income and wealth. 


\section{REFERENCES}

Abdullah, R. (2018). Segitiga pertumbuhan, kemiskinan, dan ketimpangan di Indonesia. INDEF Monthly Policy Brief, Edisi Riset Ekonomi Pembanguan, 1(3), $1-3$.

Adhinegara, B. Y., Huda, N., \& Adha, I. Al F. (2018). Pengaruh sektor e-commerce terhadap pertumbuhan ekonomi. INDEF Monthly Policy Brief, 1(2), 1-4.

Adhinegara, B.Y., Huda, N., \& Al Farras, I. (2018). Peran fintech lending dalam ekonomi Indonesia. INDEF Monthly Policy Brief, Edisi Riset Ekonomi Digital, 2(2), 1-3.

Angelsen, A., \& Wunder, S. (2006). Poverty and inequality: Economic growth is better than it's reputation. Bergen: Chapter in Dan Banik, 509-521.

Ansori, A. (2016). Digitalisasi ekonomi syariah. Jurnal Ekonomi Keuangan dan Bisnis Islam, IAIN Sultan Maulana Hasanuddin Banten, 7(1), 1-18.

Azali, K. (2017). Indonesia's divided digital economy. Singapore : ISEAS Yusof Ishak Institute (70).

Badan Kebijakan Fiskal KEMENKEU RI. (2018). Teknologi keuangan (fintech): konsep dan implementasinya di Indonesia. Warta Fiskal. Jakarta : Nizar, Muhammad. Retrieved October, 2018, from http://www.fiskal.kemenkeu. go.id/kliping/wartafiskal/2016/pdf/edisi-6-2016.pdf

BKPM (Badan Koordinasi Penanaman Modal). (2018). Siaran Pers: Dukung pengembangan ekonomi digital, bkpm-pemprov dki jakarta tandatangani nota kesepahaman. Jakarta Darmawan, I, et al. Retrieved October, 2018, from https://www.bkpm.go.id/images/uploads/file_siaran_pers/Siaran_Pers_ BKPM_09072018_Perkuat_Kerjasama_Investasi\%2C_BKPM_dan_Bank_of_ China_Tandatangani_Nota_Kesepahaman.pdf.

BKPM (Badan Koordinasi Penanaman Modal). (2018). Siaran Pers : BKPM dorong kemitraan startups Indonesia dengan investor Australia. Jakarta : Moertiningroem, Sri. Retrieved October, 2018, from https://www.bkpm.go.id/ id/publikasi/siaran-pers/readmore/641001/29001.

BPS (Badan Pusat Statistik). (2018). PDRB Provinsi-Provinsi di Indonesia Menurut Lapangan Usaha. Jakarta : BPS RI.

BPS (Badan Pusat Statistik). (2008). Tabel Input Output (I-O) 2008. BPS Kabupaten Bandung.

BPS (Badan Pusat Statistik). (2008). Tabel Input Output (I-O) Indonesia 2008. BPS RI. BPS (Badan Pusat Statistik). (2018). Ketimpangan Pendapatan (Ukuran Bank Dunia). Retrieved February, 2019, from https://sirusa.bps.go.id/index. php? $r=$ indikator/view\&id=21.

BPS (Badan Pusat Statistik). (2018). Gini Rasio. Retrieved February, 2019, from https://sirusa.bps.go.id/index.php?r=indikator/view\&id=999.

BSM. (2016). Financial technology dan lembaga keuangan. gathering mitra linkage Bank Syariah Mandiri at Hotel Grand Aston Yogyakarta. Yogyakarta : Iman, N. Retrieved October, 2018, from http://nofieiman.com/wp-content/images/ financial-technology-lembaga-keuangan.pdf

Contan.co.id. (2018). Fintech dana syariah kantongi izin dari OJK. Jakarta : Sari, Ferrika. Retrieved October, 2018, from https://keuangan.kontan.co.id/news/ fintech-dana-syariah-kantongi-izin-dari-ojk.

DBSI. (2018). "Mendorong Wirausaha Baru di Era Digital". Jakarta : Author. Retrieved October, 2018, from https://www.dbs.com. 
DDS. (2017). Kajian bisnis fintech syariah. Bandung: Telkom Digital Services.

Firmansyah. (2006). Operasi matrix dan analisis input-output (I-O) untuk ekonomi. Semarang: Badan Penerbit Universitas Diponegoro.

Google Temasek. (2018). E-Conomy SEA 2018 : Southeast Asia's internet economy hits an inflection point. Singapore : Author.

KEMKOMINFO. (2017). Laporan Tahunan Kementerian Komunikasi dan Informatika 2017. Jakarta : KEMKOMINFO.

Kemp, S. (2018). Digital in 2018 essential insights into internet, social media, mobile, and ecommerce use around the world. We Are Social. 362.

Koran Sindo. (2017). Membangkitkan industri startup nasional. Jakarta : Amm. Retrieved October, 2018, from https://autotekno.sindonews.com/ read/1266843/133/membangkitkan-industri-startup-nasional-1513606306.

Muhammadiyah. (2011). Upaya pengembangan ilmu pengetahuan dan teknologi informasi dalam rangka menghadapi pergeseran pusat geopolitik, ekonomi dan budaya global ke China. Ashari, Ahmad. Retrieved October, 2018, from http://www.muhammadiyah.or.id.

Nizar, M. (2018). Pendekatan komprehensif e-commerce perspektif syariah. Perisai, 2(1), 75-86.

Robinson, J., \& Sivakumaran, M. (2018). Accelerating Indonesia's digital economy : Assigning the $700 \mathrm{mhz}$ band to mobile broadband. London : GSMA Intelligence

Shaikh, S. A. (2016). MPRA : Equitable distribution of income with growth in an islamic economy, MPRA Paper No. 68744.

The Statistics Portal. (2018). E-Commerce Indonesia. New York : Author. Retrieved October, 2018, from https://www.statista.com/outlook/243/120/ecommerce/ indonesia.

UGM. (2000). Aplikasi input output untuk perencanaan ekonomi daerah. Yogyakarta : Pusat Antar Universitas Studi Ekonomi UGM.

Widagdo, P. B. (2016). Perkembangan electronic commerce (e-commerce) di Indonesia. Researchgate Article.

Wikipedia. (2018). Pertumbuhan ekonomi. Retrieved February, 2019, from https:// id.wikipedia.org/wiki/Pertumbuhan_ekonomi.

World Bank. (2018). Malaysia's digital economy : a new driver of development. Washington : Worldbank Group. 


\section{APPENDIX}

1. Distribution of the Information and Communication sector and Other Financial Services to GDP Quarterly at Current Prices (Percent), 2014 - 2018

\begin{tabular}{lcc}
\hline \multirow{2}{*}{ Period in Quarterly } & \multicolumn{2}{c}{ Sector } \\
\cline { 2 - 3 } & $\begin{array}{c}\text { Information and } \\
\text { Communication }\end{array}$ & Other Financial Services \\
\hline$(1)$ & $(2)$ & $(3)$ \\
Q I-2014 & 3.57 & 0.53 \\
Q II-2014 & 3.49 & 0.52 \\
Q III-2014 & 3.39 & 0.51 \\
Q IV-2014 & 3.54 & 0.54 \\
Q I-2015 & 3.58 & 0.56 \\
Q II-2015 & 3.49 & 0.54 \\
Q III-2015 & 3.46 & 0.54 \\
Q IV-2015 & 3.57 & 0.56 \\
Q I-2016 & 3.63 & 0.59 \\
Q II-2016 & 3.6 & 0.57 \\
Q III-2016 & 3.58 & 0.57 \\
Q IV-2016 & 3.67 & 0.58 \\
Q I-2017 & 3.83 & 0.6 \\
Q II-2017 & 3.83 & 0.6 \\
Q III-2017 & 3.72 & 0.62 \\
Q IV-2017 & 3.8 & 0.58 \\
Q I-2018 & 3.83 & 0.61 \\
Q II-2018 & 3.73 & 0.59 \\
Q III-2018 & 3.75 & 0.61 \\
\hline
\end{tabular}

Source : BPS (Data Processed)

2. GDP Per Capita and Economic Growth of Indonesia (2010=100), 2013-2017

\begin{tabular}{lcc}
\hline Year & $\begin{array}{c}\text { GDP Per Capita } \\
\text { (thousand rupiah) }\end{array}$ & Economic Growth (\%) \\
\hline$(1)$ & $(2)$ & $(3)$ \\
2013 & 32,781 & 5.56 \\
2014 & 33,965 & 5.01 \\
2015 & 35,162 & 4.88 \\
2016 & 36,469 & 5.03 \\
2017 & 37,851 & 5.07 \\
\hline
\end{tabular}

Source : BPS 
3. Information and Communication Growth Rate, Other Financial Services, and GDP (percent) Quarterly to the Same Quarter of Previous Year (y-on-y), 20142018 (Constant Price 2010)

\begin{tabular}{lccc}
\hline Period in Quarterly & $\begin{array}{c}\text { Information and } \\
\text { Communication }\end{array}$ & $\begin{array}{c}\text { Other Financial } \\
\text { Services }\end{array}$ & GDP \\
\hline$(1)$ & $(2)$ & $(3)$ & $(4)$ \\
Q I-2014 & 9.89 & 6.59 & 5.12 \\
Q II-2014 & 10.72 & 7.76 & 4.94 \\
Q III-2014 & 9.75 & 7.75 & 4.93 \\
Q IV-2014 & 10.12 & 7.78 & 5.05 \\
Q I-2015 & 9.66 & 8.03 & 4.83 \\
Q II-2015 & 9.25 & 7.88 & 4.74 \\
Q III-2015 & 10.65 & 7.84 & 4.78 \\
Q IV-2015 & 9.24 & 8.17 & 5.15 \\
Q I-2016 & 7.58 & 9.25 & 4.94 \\
Q II-2016 & 9.31 & 9.11 & 5.21 \\
Q III-2016 & 8.93 & 9.41 & 5.03 \\
Q IV-2016 & 9.62 & 9.18 & 4.94 \\
Q I-2017 & 10.48 & 7.19 & 5.01 \\
Q II-2017 & 11.06 & 9.46 & 5.01 \\
Q III-2017 & 8.82 & 14.96 & 5.06 \\
Q IV-2017 & 8.99 & 5.24 & 5.19 \\
Q I-2018 & 8.52 & 7.74 & 5.06 \\
Q II-2018 & 5.93 & 5.49 & 5.27 \\
Q III-2018 & 8.98 & 4.05 & 5.17 \\
\hline Source: BPS & & &
\end{tabular}

4. Gini Ratio and Poor Indonesian People (\%), 2013 (March) - 2018 (March)

\begin{tabular}{lcc}
\hline Period & Gini Ratio & Poor People (\%) \\
\hline (1) & $(2)$ & $(3)$ \\
2013 (March) & 0.413 & 11.37 \\
2013 (September) & 0.406 & 11.47 \\
2014 (March) & 0.406 & 11.25 \\
2014 (September) & 0.414 & 10.96 \\
2015 (March) & 0.408 & 11.22 \\
2015 (September) & 0.402 & 11.13 \\
2016 (March) & 0.397 & 10.86 \\
2016 (September) & 0.394 & 10.7 \\
2017 (March) & 0.393 & 10.64 \\
2017 (September) & 0.391 & 10.12 \\
2018 (March) & 0.389 & 9.82 \\
\hline Source: BPS
\end{tabular}


5. I-O Table of the calculation result of the impact analysis before being given shock (Million IDR)

\begin{tabular}{|c|c|c|c|c|c|c|c|c|}
\hline \multicolumn{2}{|r|}{ Sektor } & Household Consumption & Government Consumption & Investment (PMTB) & Inventory & Goods Export & Services Export & Final Demand \\
\hline \multicolumn{2}{|r|}{ Code } & \begin{tabular}{|l|}
301 \\
\end{tabular} & 302 & 303 & 304 & 305 & 306 & 309 \\
\hline 1 & Padi & $167,106,395$ & $5,722,100$ & 957,255 & $7,634,226$ & $1,418,800$ & $2,270,584$ & $169,840,909$ \\
\hline 2 & Tanaman kacang-kacangan & $15,414,817$ & 265,245 & 95,889 & $1,941,329$ & 701,787 & 196,225 & $14,732,634$ \\
\hline 3 & Jagung & $72,541,960$ & 863,953 & 367,486 & $3,551,738$ & $3,975,369$ & 620,006 & $74,817,036$ \\
\hline 4 & Tanaman umbi-umbian & $29,158,557$ & 645,660 & 208,800 & $1,887,747$ & 615,400 & 468,875 & $29,209,547$ \\
\hline 5 & Sayur-sayuran dan buah-buahan & $169,542,090$ & $11,857,955$ & $1,344,122$ & $6,428,998$ & $2,281,857$ & $2,978,744$ & $181,575,769$ \\
\hline 6 & Tanaman bahan makanan lainnya & $1,639,045$ & 26,388 & 35,490 & 121,053 & 160,193 & 34,699 & $1,774,762$ \\
\hline 7 & Karet & $15,832,612$ & 650,706 & $3,955,986$ & $1,312,742$ & $14,110,262$ & 209,982 & $36,072,289$ \\
\hline 8 & Tebu & $9,241,956$ & 211,270 & 112,248 & 87,402 & 597,634 & 188,878 & $10,439,387$ \\
\hline 9 & Kelapa & $11,691,310$ & 128,779 & 366,399 & $1,234,761$ & $7,756,703$ & 162,289 & $18,870,719$ \\
\hline 10 & Kelapa sawit & $18,969,275$ & 861,498 & $2,659,996$ & $6,268,435$ & $61,160,736$ & 334,478 & $77,717,548$ \\
\hline 11 & Tembakau & $3,944,597$ & 5,630 & 5,168 & 139,098 & 124,178 & 14,743 & $3,955,219$ \\
\hline 12 & Kopi & $3,947,689$ & 75,125 & 234,041 & 796,567 & $7,401,362$ & 57,633 & $10,919,284$ \\
\hline 13 & Teh & 897,185 & 17,268 & 20,504 & 9,793 & 81,957 & 13,719 & $1,020,839$ \\
\hline 14 & Cengkeh & $2,548,054$ & 5,101 & 48,255 & 5,117 & 335,360 & 12,102 & $2,943,753$ \\
\hline 15 & Hasil tanaman serat & 205,994 & 12,863 & 35,434 & 196,853 & 350,707 & 2,252 & 804,103 \\
\hline 16 & Tanaman perkebunan lainnya & $6,481,335$ & 275,305 & 546,680 & 139,242 & $12,306,582$ & 115,897 & $19,586,557$ \\
\hline 17 & Tanaman lainnya & $17,868,931$ & 668,997 & $1,408,872$ & 620,779 & $2,585,845$ & 236,472 & $22,148,338$ \\
\hline 18 & Peternakan & $68,831,805$ & $2,117,642$ & $1,521,473$ & $2,458,838$ & $4,543,663$ & $1,359,028$ & $75,914,774$ \\
\hline 19 & Pemotongan hewan & $72,681,769$ & $2,883,550$ & $1,004,203$ & 750,270 & $3,607,173$ & $2,418,929$ & $83,345,895$ \\
\hline 20 & Unggas dan hasil-hasilnya & $102,848,959$ & $4,272,482$ & $1,685,386$ & $6,762,131$ & $1,560,359$ & $4,567,491$ & $108,172,546$ \\
\hline 21 & Kayu & $8,617,773$ & 725,224 & $25,765,071$ & $2,753,900$ & $6,087,761$ & 124,994 & $44,074,724$ \\
\hline 22 & Hasil hutan lainnya & $5,184,439$ & 93,575 & $2,125,915$ & 601,586 & $1,947,005$ & 25,809 & $9,978,329$ \\
\hline 23 & Perikanan & $173,651,604$ & $2,376,589$ & 847,235 & $6,486,635$ & $11,317,333$ & $2,061,159$ & $183,767,286$ \\
\hline 24 & Penambangan batubara dan bijih logam & $23,274,166$ & $2,365,917$ & $21,284,617$ & $40,577,952$ & $176,426,194$ & 466,064 & $264,394,910$ \\
\hline 25 & Penambangan minyak, gas dan panas bumi & $75,672,583$ & $6,123,068$ & $34,799,958$ & $26,406,307$ & $223,472,251$ & $2,480,955$ & $368,955,123$ \\
\hline 26 & Penambangan dan penggalian lainnya & $5,671,023$ & $1,821,996$ & $73,332,831$ & 190,358 & $2,836,521$ & 280,124 & $84,132,852$ \\
\hline 27 & Industri pengolahan dan pengawetan makanan & $111,955,814$ & $1,759,691$ & 858,981 & $3,728,387$ & $21,717,901$ & $2,351,881$ & $134,915,880$ \\
\hline 28 & Industri minyak dan lemak & $39,568,167$ & 674,952 & 808,581 & $13,732,249$ & $168,577,902$ & 728,772 & $196,626,125$ \\
\hline 29 & Industri penggilingan padi & $239,370,424$ & $8,127,654$ & $1,239,711$ & $15,507,767$ & $1,651,027$ & $3,233,696$ & $238,114,745$ \\
\hline 30 & Industri tepung, segala jenis & $92,817,158$ & $1,112,531$ & $1,163,539$ & 498,376 & $6,734,343$ & $1,362,456$ & $103,688,402$ \\
\hline 31 & Industri gula & $20,614,428$ & 468,346 & 244,427 & 44,564 & $1,341,737$ & 419,277 & $23,043,651$ \\
\hline 32 & Industri makanan lainnya & $153,859,875$ & $3,552,309$ & $1,508,964$ & $1,213,682$ & $12,145,126$ & $2,714,053$ & $172,566,646$ \\
\hline 33 & Industri minuman & $17,092,158$ & 202,433 & 358,903 & 753,563 & 590,717 & 384,843 & $17,875,491$ \\
\hline 34 & Industri rokok & $112,192,109$ & 196,110 & 180,014 & 433,405 & $4,325,338$ & 513,535 & $117,840,511$ \\
\hline 35 & Industri pemintalan & $10,406,736$ & 284,577 & 539,417 & 732,507 & $27,188,978$ & 68,524 & $39,220,739$ \\
\hline 36 & Industri tekstil, pakaian dan kulit & $121,772,908$ & $3,289,438$ & $4,474,910$ & $15,436,082$ & $111,082,602$ & 816,359 & $256,872,299$ \\
\hline 37 & Industri bambu, kayu dan rotan & $48,888,157$ & $1,680,556$ & $68,508,413$ & $5,368,817$ & $50,011,872$ & 322,845 & $174,780,660$ \\
\hline 38 & Industri kertas, barang dari kertas dan karton & $55,947,394$ & $17,168,901$ & $9,993,831$ & 707,154 & $61,084,785$ & $1,886,392$ & $146,788,457$ \\
\hline 39 & Industri pupuk dan pestisida & $31,500,457$ & $1,455,916$ & $1,269,157$ & 482,299 & $14,067,195$ & 456,164 & $49,231,189$ \\
\hline 40 & Industri kimia & $137,934,732$ & $15,795,263$ & $41,660,041$ & $23,516,853$ & $110,943,649$ & $2,171,599$ & $284,988,430$ \\
\hline 41 & Pengilangan minyak bumi & $130,590,995$ & $10,539,526$ & $81,622,767$ & $35,648,921$ & $213,027,955$ & $7,971,031$ & $408,103,353$ \\
\hline 42 & Industri barang karet dan plastik & $104,470,435$ & $4,353,968$ & $26,144,197$ & $1,914,751$ & $92,199,314$ & $1,439,948$ & $230,522,613$ \\
\hline 43 & Industri barang-barang dari mineral bukan logam & $8,356,913$ & 898,762 & $32,097,862$ & $3,763,303$ & $6,841,529$ & 134,573 & $52,092,942$ \\
\hline 44 & Industri semen & $1,319,478$ & 549,096 & $32,512,607$ & 644,311 & $1,309,487$ & 97,119 & $36,432,098$ \\
\hline 45 & Industri dasar besi dan baja & $5,901,415$ & 741,941 & $27,335,037$ & $2,106,084$ & $16,881,292$ & 167,710 & $53,133,479$ \\
\hline 46 & Industri logam dasar bukan besi & $1,691,034$ & 163,005 & $3,586,853$ & $4,336,846$ & $57,048,994$ & 31,849 & $66,858,581$ \\
\hline 47 & Industri barang dari logam & $35,167,760$ & $5,293,973$ & $139,342,570$ & $21,582,584$ & $29,953,378$ & 742,598 & $232,082,862$ \\
\hline 48 & Industri mesin, alat-alat dan perlengkapan listrik & $173,479,864$ & $8,801,556$ & $114,460,325$ & $46,208,174$ & $133,186,911$ & $1,750,366$ & $477,887,194$ \\
\hline 49 & Industri alat pengangkutan dan perbaikannya & $159,593,401$ & $4,694,775$ & $32,354,574$ & $4,408,209$ & $50,686,552$ & $3,493,770$ & $255,231,280$ \\
\hline 50 & Industri barang lain yang belum digolongkan dimanapun & $13,815,254$ & $1,505,694$ & $3,130,540$ & $3,558,869$ & $15,206,822$ & 161,394 & $30,260,835$ \\
\hline 51 & Listrik, gas dan air bersih & $81,199,897$ & $6,202,981$ & $15,670,875$ & $1,434,044$ & $18,125,140$ & $1,857,767$ & $124,490,705$ \\
\hline 52 & Bangunan & $43,008,040$ & $19,358,384$ & $1,160,012,469$ & 895,131 & $17,261,724$ & $3,439,787$ & $1,243,975,535$ \\
\hline 53 & Perdagangan & $575,973,859$ & $23,375,895$ & $160,140,816$ & $7,857,351$ & $220,028,195$ & $11,746,629$ & $999,122,745$ \\
\hline 54 & Restoran dan hotel & $257,219,817$ & $16,343,493$ & $14,325,534$ & 405,361 & $8,046,161$ & $40,758,876$ & $337,099,241$ \\
\hline 55 & Angkutan kereta api & $4,691,342$ & 282,779 & 469,138 & 35,148 & 503,186 & 238,764 & $6,220,357$ \\
\hline 56 & Angkutan darat & $167,087,588$ & $10,107,625$ & $38,094,773$ & $2,273,017$ & $46,233,146$ & $3,445,853$ & $267,242,003$ \\
\hline 57 & Angkutan air & $25,138,810$ & $1,150,951$ & $8,262,355$ & 561,218 & $11,856,989$ & $27,648,753$ & $74,619,075$ \\
\hline 58 & Angkutan udara & $47,021,777$ & $6,506,477$ & $4,119,062$ & 318,086 & $4,476,784$ & $7,966,271$ & $70,408,458$ \\
\hline 59 & Jasa penunjang angkutan & $22,794,028$ & $2,793,516$ & $6,913,606$ & 514,612 & $8,969,473$ & $8,984,400$ & $50,969,634$ \\
\hline 60 & Komunikasi (ICT, e-commerce, etc) & $131,096,023$ & $5,646,758$ & $16,076,120$ & 816,782 & $14,281,426$ & $22,724,987$ & $190,642,096$ \\
\hline 61 & Lembaga keuangan (Fintech, etc) & $163,177,097$ & $13,207,993$ & $40,169,962$ & $1,204,351$ & $43,769,397$ & $9,167,296$ & $270,696,096$ \\
\hline 62 & Real estat dan jasa perusahaan & $182,690,209$ & $9,830,300$ & $52,599,787$ & $2,230,713$ & $30,866,029$ & $17,716,430$ & $295,933,468$ \\
\hline 63 & Pemerintahan umum dan pertahanan & $20,466,641$ & $246,975,472$ & $1,687,623$ & 65,782 & $1,308,939$ & $4,782,532$ & $275,286,989$ \\
\hline 64 & \begin{tabular}{|l} 
Jasa sosial kemasyarakatan \\
\end{tabular} & $137,915,019$ & $170,116,316$ & $5,253,549$ & 83,970 & $3,107,285$ & $14,132,496$ & $330,608,637$ \\
\hline 65 & Jasa lainnya & $192,987,793$ & $20,377,131$ & $39,487,368$ & $1,532,353$ & $27,832,452$ & $8,316,161$ & $290,533,258$ \\
\hline 66 & Kegiatan yang tak jelas batasannya & $3,348,231$ & 24,258 & 183,106 & 11,937 & 292,458 & 9,316 & $3,869,306$ \\
\hline
\end{tabular}

Source : BPS 
6. I-O Table of the calculation result of the impact analysis after being given shock (Million IDR)

\begin{tabular}{|c|c|c|c|c|c|c|c|c|}
\hline & Household Consumption & Government Consumption & Investment (PMTB) & Inventory & Goods Export & Services Export & Final Demand \\
\hline & Code & 301 & 302 & 303 & 304 & 305 & 306 & 309 \\
\hline 1 & Padi & $167,106,395$ & $5,722,100$ & 958,507 & $7,634,226$ & $1,418,800$ & $2,270,584$ & $169,842,161$ \\
\hline 2 & Tanaman kacang-kacangan & $15,414,817$ & 265,245 & 95,982 & $1,941,329$ & 701,787 & 196,225 & $14,732,727$ \\
\hline 3 & Jagung & $72,541,960$ & 863,953 & 367,864 & $3,551,738$ & $3,975,369$ & 620,006 & $74,817,414$ \\
\hline 4 & Tanaman umbi-umbian & $29,158,557$ & 645,660 & 209,012 & $1,887,747$ & 615,400 & 468,875 & $29,209,759$ \\
\hline 5 & Sayur-sayuran dan buah-buahan & $169,542,090$ & $11,857,955$ & $1,346,400$ & $6,428,998$ & $2,281,857$ & $2,978,744$ & $181,578,047$ \\
\hline 6 & Tanaman bahan makanan lainnya & $1,639,045$ & 26,388 & 35,515 & 121,053 & 160,193 & 34,699 & $1,774,788$ \\
\hline 7 & Karet & $15,832,612$ & 650,706 & $3,957,926$ & $1,312,742$ & $14,110,262$ & 209,982 & $36,074,229$ \\
\hline 8 & Tebu & $9,241,956$ & 211,270 & 112,351 & 87,402 & 597,634 & 188,878 & $10,439,490$ \\
\hline 9 & Kelapa & $11,691,310$ & 128,779 & 366,463 & $1,234,761$ & $7,756,703$ & 162,289 & $18,870,783$ \\
\hline 10 & Kelapa sawit & $18,969,275$ & 861,498 & $2,660,807$ & $6,268,435$ & $61,160,736$ & 334,478 & $77,718,359$ \\
\hline 11 & Tembakau & $3,944,597$ & 5,630 & 5,171 & 139,098 & 124,178 & 14,743 & $3,955,222$ \\
\hline 12 & Kopi & $3,947,689$ & 75,125 & 234,074 & 796,567 & $7,401,362$ & 57,633 & $10,919,316$ \\
\hline 13 & Teh & 897,185 & 17,268 & 20,512 & 9,793 & 81,957 & 13,719 & $1,020,847$ \\
\hline 14 & Cengkeh & $2,548,054$ & 5,101 & 48,258 & 5,117 & 335,360 & 12,102 & $2,943,756$ \\
\hline 15 & Hasil tanaman serat & 205,994 & 12,863 & 35,447 & 196,853 & 350,707 & 2,252 & 804,116 \\
\hline 16 & Tanaman perkebunan lainnya & $6,481,335$ & 275,305 & 546,900 & 139,242 & $12,306,582$ & 115,897 & $19,586,777$ \\
\hline 17 & Tanaman lainnya & $17,868,931$ & 668,997 & $1,409,202$ & 620,779 & $2,585,845$ & 236,472 & $22,148,669$ \\
\hline 18 & \begin{tabular}{|l|l} 
Peternakan \\
\end{tabular} & $68,831,805$ & $2,117,642$ & $1,522,128$ & $2,458,838$ & $4,543,663$ & $1,359,028$ & $75,915,428$ \\
\hline 19 & Pemotongan hewan & $72,681,769$ & $2,883,550$ & $1,005,168$ & 750,270 & $3,607,173$ & $2,418,929$ & $83,346,859$ \\
\hline 20 & Unggas dan hasil-hasilnya & $102,848,959$ & $4,272,482$ & $1,686,685$ & $6,762,131$ & $1,560,359$ & $4,567,491$ & $108,173,846$ \\
\hline 21 & Kayu & $8,617,773$ & 725,224 & $25,767,723$ & $2,753,900$ & $6,087,761$ & 124,994 & $44,077,376$ \\
\hline 22 & Hasil hutan lainnya & $5,184,439$ & 93,575 & $2,126,190$ & 601,586 & $1,947,005$ & 25,809 & $9,978,604$ \\
\hline 23 & Perikanan & $173,651,604$ & $2,376,589$ & 847,950 & $6,486,635$ & $11,317,333$ & $2,061,159$ & $183,768,001$ \\
\hline 24 & Penambangan batubara dan bijih logam & $23,274,166$ & $2,365,917$ & $21,294,371$ & $40,577,952$ & $176,426,194$ & 466,064 & $264,404,664$ \\
\hline 25 & Penambangan minyak, gas dan panas bumi & $75,672,583$ & $6,123,068$ & $34,817,086$ & $26,406,307$ & $223,472,251$ & $2,480,955$ & $368,972,251$ \\
\hline 26 & Penambangan dan penggalian lainnya & $5,671,023$ & $1,821,996$ & $73,338,710$ & 190,358 & $2,836,521$ & 280,124 & $84,138,731$ \\
\hline 27 & Industri pengolahan dan pengawetan makanan & $111,955,814$ & $1,759,691$ & 859,617 & 3,728,387 & $21,717,901$ & $2,351,881$ & $134,916,516$ \\
\hline 28 & Industri minyak dan lemak & $39,568,167$ & 674,952 & 808,997 & $13,732,249$ & $168,577,902$ & 728,772 & $196,626,541$ \\
\hline 29 & Industri penggilingan padi & $239,370,424$ & $8,127,654$ & $1,241,315$ & $15,507,767$ & $1,651,027$ & $3,233,696$ & $238,116,349$ \\
\hline 30 & Industri tepung, segala jenis & $92,817,158$ & $1,112,531$ & $1,165,252$ & 498,376 & $6,734,343$ & $1,362,456$ & $103,690,115$ \\
\hline 31 & Industri gula & $20,614,428$ & 468,346 & 244,658 & 44,564 & $1,341,737$ & 419,277 & $23,043,883$ \\
\hline 32 & Industri makanan lainnya & $153,859,875$ & $3,552,309$ & $1,510,483$ & $1,213,682$ & $12,145,126$ & $2,714,053$ & $172,568,165$ \\
\hline 33 & Industri minuman & $17,092,158$ & 202,433 & 359,449 & 753,563 & 590,717 & 384,843 & $17,876,037$ \\
\hline 34 & Industri rokok & $112,192,109$ & 196,110 & 180,126 & 433,405 & $4,325,338$ & 513,535 & $117,840,623$ \\
\hline 35 & Industri pemintalan & $10,406,736$ & 284,577 & 540,026 & 732,507 & $27,188,978$ & 68,524 & $39,221,348$ \\
\hline 36 & Industri tekstil, pakaian dan kulit & $121,772,908$ & $3,289,438$ & $4,481,980$ & $15,436,082$ & $111,082,602$ & 816,359 & $256,879,369$ \\
\hline 37 & Industri bambu, kayu dan rotan & $48,888,157$ & $1,680,556$ & $68,514,534$ & $5,368,817$ & $50,011,872$ & 322,845 & $174,786,781$ \\
\hline 38 & Industri kertas, barang dari kertas dan karton & $55,947,394$ & $17,168,901$ & $10,038,440$ & 707,154 & $61,084,785$ & $1,886,392$ & $146,833,067$ \\
\hline 39 & Industri pupuk dan pestisida & $31,500,457$ & $1,455,916$ & $1,269,895$ & 482,299 & $14,067,195$ & 456,164 & $49,231,926$ \\
\hline 40 & Industri kimia & $137,934,732$ & $15,795,263$ & $41,676,818$ & $23,516,853$ & $110,943,649$ & $2,171,599$ & $285,005,207$ \\
\hline 41 & Pengilangan minyak bumi & $130,590,995$ & $10,539,526$ & $81,661,512$ & $35,648,921$ & $213,027,955$ & $7,971,031$ & $408,142,098$ \\
\hline 42 & Industri barang karet dan plastik & $104,470,435$ & $4,353,968$ & $26,157,557$ & $1,914,751$ & $92,199,314$ & $1,439,948$ & $230,535,973$ \\
\hline 43 & Industri barang-barang dari mineral bukan logam & $8,356,913$ & 898,762 & $32,100,729$ & $3,763,303$ & $6,841,529$ & 134,573 & $52,095,809$ \\
\hline 44 & Industri semen & $1,319,478$ & 549,096 & $32,515,163$ & 644,311 & $1,309,487$ & 97,119 & $36,434,654$ \\
\hline 45 & Industri dasar besi dan baja & $5,901,415$ & 741,941 & $27,337,862$ & 2,106,084 & $16,881,292$ & 167,710 & $53,136,304$ \\
\hline 46 & Industri logam dasar bukan besi & $1,691,034$ & 163,005 & $3,587,529$ & 4,336,846 & $57,048,994$ & 31,849 & $66,859,257$ \\
\hline 47 & Industri barang dari logam & $35,167,760$ & $5,293,973$ & $139,357,894$ & $21,582,584$ & $29,953,378$ & 742,598 & $232,098,186$ \\
\hline 48 & Industri mesin, alat-alat dan perlengkapan listrik & $173,479,864$ & $8,801,556$ & $114,525,399$ & $46,208,174$ & $133,186,911$ & $1,750,366$ & $477,952,269$ \\
\hline 49 & Industri alat pengangkutan dan perbaikannya & $159,593,401$ & $4,694,775$ & $32,364,989$ & 4,408,209 & $50,686,552$ & $3,493,770$ & $255,241,695$ \\
\hline 50 & Industri barang lain yang belum digolongkan dimanapun & $13,815,254$ & $1,505,694$ & $3,131,264$ & $3,558,869$ & $15,206,822$ & 161,394 & $30,261,559$ \\
\hline 51 & Listrik, gas dan air bersih & $81,199,897$ & $6,202,981$ & $15,730,933$ & $1,434,044$ & $18,125,140$ & $1,857,767$ & $124,550,763$ \\
\hline 52 & Bangunan & $43,008,040$ & $19,358,384$ & $1,160,103,464$ & 895,131 & $17,261,724$ & $3,439,787$ & $1,244,066,530$ \\
\hline 53 & Perdagangan & $576,008,448$ & $23,377,299$ & $160,199,730$ & $7,857,823$ & $220,041,408$ & $11,747,335$ & $999,232,043$ \\
\hline 54 & Restoran dan hotel & $257,219,817$ & $16,343,493$ & $14,333,776$ & 405,361 & $8,046,161$ & $40,758,876$ & $337,107,483$ \\
\hline 55 & Angkutan kereta api & $4,691,342$ & 282,779 & 470,697 & 35,148 & 503,186 & 238,764 & $6,221,916$ \\
\hline 56 & Angkutan darat & $167,087,588$ & $10,107,625$ & $38,115,451$ & $2,273,017$ & $46,233,146$ & $3,445,853$ & $267,262,680$ \\
\hline 57 & Angkutan air & $25,138,810$ & $1,150,951$ & $8,266,842$ & 561,218 & $11,856,989$ & $27,648,753$ & $74,623,562$ \\
\hline 58 & Angkutan udara & $47,021,777$ & $6,506,477$ & $4,130,359$ & 318,086 & $4,476,784$ & $7,966,271$ & $70,419,755$ \\
\hline 59 & Jasa penunjang angkutan & $22,794,028$ & $2,793,516$ & $6,920,864$ & 514,612 & $8,969,473$ & $8,984,400$ & $50,976,892$ \\
\hline 60 & Komunikasi (ICT, e-commerce, etc) & $131,096,023$ & $5,646,758$ & $20,269,476$ & 816,782 & $14,281,426$ & $22,724,987$ & $194,835,452$ \\
\hline 61 & Lembaga keuangan (Fintech, etc) & $163,382,895$ & $13,224,651$ & $40,362,724$ & $1,205,870$ & $43,824,599$ & $9,178,858$ & $271,179,597$ \\
\hline 62 & Real estat dan jasa perusahaan & $182,690,209$ & $9,830,300$ & $52,692,944$ & $2,230,713$ & $30,866,029$ & $17,716,430$ & $296,026,625$ \\
\hline 63 & Pemerintahan umum dan pertahanan & $20,466,641$ & $246,975,472$ & 1,699,024 & 65,782 & 1,308,939 & $4,782,532$ & $275,298,390$ \\
\hline 64 & Jasa sosial kemasyyarakatan & $137,915,019$ & $170,116,316$ & $5,277,179$ & 83,970 & $3,107,285$ & $14,132,496$ & $330,632,267$ \\
\hline 65 & Jasa lainnya & $192,987,793$ & $20,377,131$ & $39,569,472$ & $1,532,353$ & $27,832,452$ & $8,316,161$ & $290,615,362$ \\
\hline 66 & Kegiatan yang tak jelas batasannya & $3,348,231$ & 24,258 & 183,176 & 11,937 & 292,458 & 9,316 & $3,869,376$ \\
\hline
\end{tabular}

Source : BPS (data processing) 